\title{
Control of the South American fruit fly in pear fruits with natural-based products
}

\author{
Marcelo Zanelato Nunes ${ }^{1 *}$, Mari Inês Carissimi Boff', Régis Sivori Silva dos Santos², \\ Cláudio Roberto Franco', Joatan Machado da Rosa'
}

\author{
'Santa Catarina State University, Centre of Agroveterinarian Sciences, Lages, SC, Brazi \\ ${ }^{2}$ razilian Agricultural Research Corporation, Temperate Fruit Station, Vacaria, RS, Brazil \\ *Corresponding author, e-mail: znunes.marcelo@gmail.com
}

\begin{abstract}
This study aimed to assess, in laboratory conditions, the effect of andiroba oil (2L $\left.100 \mathrm{~L}^{-1}\right)$, kaolin $\left(7.5 \mathrm{Kg} 100 \mathrm{~L}^{-1}\right)$, azadirachtin $\left(2.5 \mathrm{~L} 100 \mathrm{~L}^{-1}\right)$, metidationa $\left(100 \mathrm{~mL} 100 \mathrm{~L}^{-1}\right)$ and distilled water (control) on the oviposition and mortality of adults of A.fraterculus in no-choice and free-choice tests. The experimental design was randomized with five treatments and 20 replicatesfor the no-choice test; and 15 replicates for the free-choice test. Fruits were immersed in each treatment solution, dried at room temperature and placed in pots with two couples of $A$. fraterculus (no-choice test) and in arenas with four couples along with a fruit that was previously immersed in water (free-choice test). Twenty-five days after infestation, fruits were dissecated and the number of larvae was recorded as well the number of pupae and adults. Only methidathion was effective on adults with mortality of 91.3\% $(P<0.05)$. There was no larval emergence and, consequently, pupae and adult development in fruits treated with andiroba oil and methidathion in both tests. Azadirachtin and kaolin did not present any effect on A. fraterculus. Andiroba oil was effective on the reduction of the infestation of pear fruits by $A$. fraterculus.
\end{abstract}

Keywords: Anastrepha fraterculus, essential oils, development, toxicity

\section{Controle da mosca-das-frutas Sul-Americana em frutos de pera com produtos de origem natural}

\section{Resumo}

O objetivo deste estudo foi avaliar, em condições de laboratório, o efeito de óleo de andiroba (2L

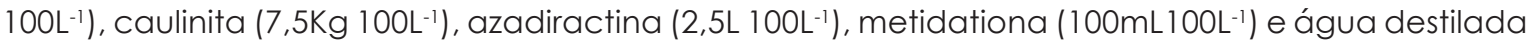
(controle) sobre a oviposição e mortalidade de adultos de A. fraterculus em testes com e sem chance de escolha. O delineamento experimental foi inteiramente casualizado com 20 repetições no teste sem chance de escolha e 15 repetições no teste com chance de escolha. Frutos foram imersos nos tratamentos, secos a temperatura ambiente e colocados em potes com dois casais de A. fraterculus (sem chance de escolha) e em arenas com quatro casais juntamente com um fruto previamente imerso em água (com chance de escolha). Vinte e cinco dias após a infestação, os frutos foram dissecados e o número de larvas vivas foi quantificado bem como o número de pupas e adultos. Apenas metidationa mostrou-se eficaz sobre adultos com $91,3 \%$ de mortalidade. Não houve emergência de larvas e consequentemente nem o desenvolvimento de pupas e adultos nos frutos tratados com óleo de andiroba e metidationa em ambos os testes. Azadiractina e caulim não apresentaram efeito sobre A. fraterculus. Óleo de andiroba mostrou-se eficaz na redução da infestação de frutos de pera por A. fraterculus.

Palavras-chave:Anastrepha fraterculus, desenvolvimento, óleos essenciais, toxicidade 


\section{Introduction}

Anastrepha fraterculus (Widemann, 1830) (Diptera: Tephritidae) is a fruit fly species that causes damage to a wide range of fruit plants in Brazil, including the pear, and is responsible for losses that can reach up to $100 \%$ of the fruit production (Carvalho, 2006). Moreover, the damage caused by the South American fruit fly to orchards cause the increase in production costs due to the need of frequent pesticide applications (Bittencourt et al. 2006).

The control of $A$. fraterculus is based on the use of organophosphates that are fully applied in the area, or in the form of toxic baits that consist of a mix of food attractant and pesticide. However, these pesticides are highly toxic to natural enemies, to human beings, and have a high grace period (Scoz et al. 2004). The development of Integrated Pest Management (IPM) that aim to reduce pesticide usage associated with the expansion of organic agriculture has contributed to increase the search for pesticides of natural origin as for example, botanic pesticides (Zenzon et al. 2005).

Natural products are metabolites or natural compounds derived from animals or plants. In plants these compounds are products of secondary metabolism and are related to plant defenses (Hochuli, 2001; Catehouse, 2002). The use of products from plants has been widely studied on insect control (Charleston et al. 2005; Maia \& Moore, 2011). Among the promising compounds there is the azadirachtin, extracted from Meliaceae plants, and the andiroba oil that is extracted from the seeds of Carapa guianensis Aubl, (Meliaceae). Plants of the Meliaceae family are known to have substances called limonoids, which have a wide spectrum of biological activities mainly as pesticide (Champagne et al. 1992).

Other promising product derived from minerals is the kaolin, which is formed by aluminum hydroxide silicate and has been tested and used for the control of insects in fruit trees (Leskey, 2010). This technology has as principle the formation of a physical barrier that make the plant unrecognizable to a specific insect pest (Lemoyne et al. 2008). In addition, kaolin particles also work adhering to the body of insects and interfering on their movements, feeding and oviposition behaviors (Cottrel et al. 2002).

The use of botanical pesticides and substances that work as particle films on fruits has become greatly important for the Integrated and Ecological Pest Management, and further studies should be conducted on how it can affect pests, to subsequently aid on the development of techniques that should be effective and environmentally friendly.

Considering the damage cause by the South American fruit fly and the possibility of its control with natural products, the present study aimed to evaluate the insecticidal effect of natural compounds on $A$. fraterculus.

\section{Material and Methods}

Adult flies of $A$. fraterculus belonging to an eighth generation of an artificial rearing were obtained from the Laboratory of Entomology of the University of Santa Catarina. The substrate used for oviposition was papaya and the diet used for adults consisted of wheat germ, refined sugar and yeast on the proportion of 3:1:1 respectively, and water ad libitum.

Pears fruits of $\mathrm{cv}$. Williams used on this study were collected at an experimental orchard located at Experimental Station of Epagri in municipality of São Joaquim, SC (2816'33" S; 49०56'12" E; altitude of $1406 \mathrm{~m}$ ). Fruits were bagged on phenological state "J" (fruit growing) (Minost, 2013), when they had two centimeters of transversal. The harvest occurred 120 daysafter blossom.

The treatments and concentrations used in the tests were: (1) andiroba oil; (2) kaolin; (3) azadiracthin (Azamax ${ }^{\circledR}, 12 \mathrm{~g} \mathrm{~L}^{-1}$ of active ingredient); (4) methidathion (Supracid ${ }^{\circledR} 400$ EC), as standard treatmentand (5) distilled water as control. (Table 1)

The tests with adult $A$. fraterculus were performed with no-choice and free-choice, under laboratory conditions $\left(25 \pm 3{ }^{\circ} \mathrm{C}\right.$, relative humidity of $60 \pm 10 \%$ and photophase of 14 hours). The experimental design was randomized with five treatments and 20 replicatesper treatment in no-choice tests (each individualized fruit with two couples of A. fraterculus was considered as one replicate) and with 15 replicates per treatment in the free choice test. 
Table 1. Substances and doses used to treat pearfruits of $\mathrm{cv}$. Williams in choice and no-choice experiments carried on under laboratory conditions $\left(25 \pm 3^{\circ} \mathrm{C}\right.$, relative humidity of $60 \pm 10 \%$ and photo phase of 14 hours).

\begin{tabular}{cc}
\hline Treatment & Dose $100 \mathrm{~L}^{-1}$ \\
\hline Andiroba oil & $2 \mathrm{~L}$ \\
Kaolin & $7.5 \mathrm{Kg}$ \\
Azadiractin & (kaolin $7.0 \mathrm{Kg}+0.5 \mathrm{anti-caking}$ agent) \\
Methidathion & $2.5 \mathrm{~L}$ \\
Water & $100 \mathrm{~mL}$ \\
\hline
\end{tabular}

On the no choice-test, fruits were immersed on $500 \mathrm{~mL}$ of the solution formed by the mixture of each treatment and distilled water for 15 seconds. Then, the fruits were dried at room temperature during two hours. After, these fruits were placed individually on plastic pots $(750 \mathrm{~mL})$. Two couples of flies, with age between 14 and 17 days, were released for 48 hours in each pot containing one fruit, adult diet (honey diluted in water at $10 \%$, offered in hydrophilic cotton and positioned on the center of the arena)and water offered in hydrophilic cotton. The mortality of adult flies was evaluated 48 hours after their release, through counting the number of dead individuals. Were considered as dead those insects that did not present any reaction when slightly touched with a brush. After 25 days the fruits were dissected and the number of live larvae was counted. Larvae obtained from each fruit were put into plastic pots $(300 \mathrm{~mL})$ with its bottom coated with vermiculite and maintained in a temperature controlled room $\left(25 \pm 3^{\circ} \mathrm{C}\right.$, relative humidity of $60 \pm 10 \%$ and photo phase of 14 hours) until the emergence of adults, which were also quantified.

On the free-choice experiment, one fruit was immersed for 15 seconds on each treatment. After, they were dried at room temperature (25 \pm $3^{\circ} \mathrm{C}$ ) and positioned on opisite sites of an arena (34 cm of diameter and $12 \mathrm{~cm}$ high). On this test, four couples of $A$. fraterculus, with age between
14 and 17 days, were released for 48 hours. Diet was offered in the center of the arena, the same way as described for no choice test. After, the fruits were removed and each one was put into plastic pots $(750 \mathrm{~mL})$, coated with vermiculite and maintained in the same conditions as described above. The assessments made on this test follow the same protocol used on the no-choice test.

In both experiments, data related to mortality was transformed into arcsen $\sqrt{ } \mathrm{x} / 100$ and submitted to ANOVA and means compared by the Tukey's test at $5 \%$ of significance. Data referred to the number of larvae, pupae and adults obtained were transformed into $\sqrt{ } x+1$ and submitted to the $T$ test at $5 \%$ of significance.

\section{Results}

Methidation caused the death of $91 \%$ adult flies after 48 hours of exposure, and was the most effective treatment when compared to the others on the no-choice test $(P<0.05)$. Among the natural products, the andiroba oil showed an intermediary efficacy on adult mortality and differed from the other treatments $(P<0.05)$. (Table 2)

In the no-choice test, $A$. fraterculus did not develop on fruits treated with andiroba oil or methidathion, whereas on fruits submitted to the other treatments, infestation was similar to control $(P<0.05)$. (Table 1)

Table2. Percentage of adult mortality, average number of larvae, pupae and adults of $A$. fraterculus in pearsfruit of $\mathrm{cv}$. Williamsimmersed in each treatment in the no-choice test in laboratory conditions $\left(25 \pm 3^{\circ} \mathrm{C}\right.$, relative humidity of $60 \pm 10 \%$ and photo phase of 14 hours).

\begin{tabular}{ccccc}
\hline Treatment & Adult mortality (\%) & Larvae & Pupae & Adults emergence \\
\hline Andirobaoil & $26.0 \mathrm{~b}$ & $0.0 \mathrm{~b}$ & $0.0 \mathrm{~b}$ & $0.0 \mathrm{~b}$ \\
Methidathion & $91.3 \mathrm{a}$ & $0.0 \mathrm{~b}$ & $0.0 \mathrm{~b}$ & $0.0 \mathrm{~b}$ \\
Kaolin & $0.0 \mathrm{c}$ & $15.0 \mathrm{a}$ & $9.4 \mathrm{a}$ & $9.2 \mathrm{a}$ \\
Azadirachtin & $2.5 \mathrm{c}$ & $8.8 \mathrm{a}$ & $6.7 \mathrm{ab}$ & $6.3 \mathrm{ab}$ \\
Control & $0.0 \mathrm{c}$ & $13.1 \mathrm{a}$ & $10.9 \mathrm{a}$ & $6.6 \mathrm{a}$ \\
\hline
\end{tabular}

Means followed by the same letter on each columndonot significantly differby Tukey's test $(P<0.05)$. 
In the free-choice test Methidathion exhibited efficiency of $30.9 \%$ on adult mortality and was the only treatment that differed from the kaolin (3.4\%). While andiroba oil and azadirachtin showed mortality of 15.9 and $20.0 \%$, respectively. The average alive larvae, found in the treatments andiroba oil and methidathion differed significantly from control and no pupae, nor adults were found on these treatments. The opposite occurred with azadirachtin, which presented higher number of larvae in relation to control $(P<0.05$ Table 3).

Table 3. Percentage of adult mortality, average number of larvae, pupae and adults of A. fraterculus in pears fruit of $\mathrm{cv}$. Williams immersed in each treatment in thein the free-choice test in laboratory conditions $\left(25 \pm 3^{\circ} \mathrm{C}\right.$, relative humidity of $60 \pm 10 \%$ and photophase of 14 hours).

\begin{tabular}{|c|c|c|c|c|c|c|c|}
\hline \multirow{2}{*}{ Treatment } & \multirow{2}{*}{ Mortality (\%) } & \multicolumn{2}{|c|}{ Larvae } & \multicolumn{2}{|c|}{ Pupae } & \multicolumn{2}{|c|}{ Adults } \\
\hline & & Treatment & Control* & Treatment & Control* & Treatment & Control* \\
\hline Andiroba oil & $15.9 a b$ & $2.7^{*}$ & 18.9 & $0.00 *$ & 9.1 & $0.0 *$ & $8.2 \mathrm{~b}$ \\
\hline Methidathion & $30.9 \mathrm{a}$ & $0.0^{*}$ & 11.9 & $0.0^{*}$ & $9.3 b$ & $0.0^{*}$ & $4.7 \mathrm{~b}$ \\
\hline Kaolin & $3.4 \mathrm{~b}$ & 8.9 & 11.5 & 5.7 & 5.4 & 3.4 & $2.9 \mathrm{a}$ \\
\hline Azadirachtin & $20.0 \mathrm{ab}$ & 10.5 & 5.5 & 5.5 & 2.7 & 2.5 & $0.4 a$ \\
\hline
\end{tabular}

\section{Discussion}

Unlike the no-chance test, low mortality was found for the methidathion treatment on the free-chance test. This fact may be related to how this pesticide acts on the insect, which is by ingestion and through contact (Agrofit, 2013), thus only the insects that landed on the fruit were poisoned.

The absence of larvae in fruits treated with andiroba oil suggests that oviposition was hindered by the release of inhibiting compounds or when the flies touched the oily film. Studies where the andiroba oil has been used on the management of important crop pests are still preliminary. However, there are studies that prove a repellent effect of this substance on Aedes sp. (Diptera: Culicidae). In a research done by Freire et al. (2006), which the objective was to study the effects of andiroba and copaiba oils on Phoridae pests of meliponine bee hives, it was observed that females of this family avoided ovipositing on pots that contained a mixture of pollen and andiroba oil. However, no effect was observed when the andiroba oil was tested on Phoridae larvae. With respect to fruit flies, Rosa et al. (2013) mixed andiroba oil at 1 and $2 \%$ with hydrolyzed proteinat $5 \%$ (that is used on the monitoring of A. fraterculus in feijoa orchards) and observed a reduction of the flies capture compared to hydrolyzed protein (5\%) alone.

The andiroba oil is formed by a complex of six limonoids (Ambrozin, 2006), which gedunin appears in highest amount. This phytochemical has proven to affect feeding larvae and the development of Lepidoptera (Champagne et al. 1992). Despite de evidences related to the presence of compounds that can grant a phagodeterrent activity to andiroba oil, Hidayat et al. (2013) showed that vegetable oils create a slippery surface, and females are unable to puncture the fruit skin for egg deposition. This result is in agreement whith that observed by Daniel (2014), in that females of Rhagoletis cerasi(L.) (Diptera: Tephritidae) changed their oviposition and spent more time trying to oviposit on fruits treated with rapeseed oil and Naturalis-L ${ }^{\circledR}$, a biocontrol product which contains oil as formulant.

Contrary to the results obtained with azadirachtin on this study, Khattak et al. (2009) found that neem extracts reduced the infestation of Bactrocera curcubitae (Coquillett) (Diptera: Tephritidae) in melons. Evidences of neem activities on $C$. capitata were also found by Silva et al. (2013), according to these authors, extracts of neem in dichloromethane (888 ppm) are capable of reduce fecundity and fertility of the Mediterranean fruit fly. In chewing insects, azadirachtin is listed as a growth regulator (Isman, 2006; Nunes et al. 2013). However, fruit growers have not confirmed the effects of the application of azadirachtin on adults of the Sulamerican fruit fly in field conditions (Gonçalves et al. 2005).

In this present work, pears treated with kaolin did not show significant difference on the number of larvae and pupae nor reduction on 
the mortality of $A$. fraterculus adults in relation to control. However, positive results were found by Braham et al. (2007) and Verde et al. (2011), who have found reduced damage on fruit treated with kaolin when exposed to Ceratitis capitata (Wiedemann, 1824) (Diptera: Tephritidae) adults in field conditions. Positive results of kaolin in the field since kaolin changes the tonality of the plant color. When the plant changes its color, phytophagous insects may be unable to recognize it, since many of them, including the fruit flies, use visual stimuli to reach the host plant (Glen \& Puterka, 2005); that does not occur in confined conditions in which the fruit range is very small.

\section{Conclusions}

Through the results found on this study indicate that andiroba oil interferes negatively with in biology of $A$. fraterculus in no choice and free-choice tests, promoting the reduction of its population in medium term.

\section{References}

AGROFIT. 2013. http://agrofit.agricultura. gov.br/agrofit_cons/principal_agrofit_cons. <Accessedon 22 Jan. 2013.>

Ambrozin, A.R.P., Leite, A.C.; Bueno, F.C., Vieira, P.C., Fernandes, J.B., Bueno, O.C., Silva, M.F.G.F.,Pagnocca, F.C., Hebling, M.J.A., Junior, M.B. 2006.Limonoids from Andiroba oil and Cedrela fissilis and their insecticidal activity. Journal of the Brazilian Chemical Society 17: 542547.

Bittencourt, A.L,Cova. A.K.W., Silva, A.C.M., Silva, V.E.S.,Bomfim, Z.V., Araujo. E.L., Souza-Filho, M.F. 2006. Espécies de moscas-das-frutas (Tephritidae) obtidas em armadilhas McPhail no Estado da Bahia, Brasil. Semina: Ciências Agrárias 27: 561 564.

Braham, M., Pasqualini, E.,Ncira, N. 2007. Efficacy of kaolin, spinosad and malathion against Ceratitis capitata in Citrus orchards. Bulletin of insectology 60: 39-47.

Carvalho, R.S. 2006. Biocontrole de moscas-dasfrutas: histórico, conceitos e estratégias. Embrapa mandioca e fruticultura tropical, Cruz das Almas, Brasil. 5p. (Circular Técnica, 83).

Catehouse, J.A. 2002. Plant resistance toward insect herbivores: a dynamic interaction. New Phytologist 156: 145-169.

Charleston, D.S., Kfir, R., Vet, L.E.M.,Dicke, M.
2005. Behavioural responses of diamondback moth Plutella xylostella (Lepidoptera: Plutellidae) to extracts derived from Melia azedarach and Azadirachta indica. Bulletin of Entomological Research 95: 457-465.

Champagne, D.E., Koul, O.,Isman, M.B., Scudder, G.G.E., Towers, G.H. 1992. Biological activity of limonoids from the rutales. Phytochemistry 31: 377-394.

Cottrel, T.E.,Wood, B.W.,Reilly, C.C. 2002. Particle film affects black pecan aphid (Homoptera: Aphididae) on pecan. Journal of Economic Entomology 95:782-788.

Daniel, C. 2014. Rhagoletis cerasi: Oviposition reduction effects of oil products. Insects 5: 319331.

Freire, D.C.B., Brito-Filho, C.R.C., Carvalho-Zilse, G.A. 2006. Efeito dos óleos vegetais de andiroba (Carapasp.) e Copaíba (Copaiferasp.) sobre forídeos, pragas de colméias, (Diptera: Phoridae) na Amazônia Central. Acta Amazônica 36: 365368.

Glenn, D.M., Puterka, G.J. 2005. Particles films: a new technology for agriculture. Horticultural Reviews 31: 1-44.

Gonçalves, P.A.S., Debarba, J.F., Keske, C. 2005. Incidência da mosca-das-frutas, Anastrepha fraterculus (Diptera: Tephritidae), em cultivares de ameixa conduzidas sob sistema orgânico. Revista de Ciências Agroveterinárias 4: 101-108.

Hidayat, Y., Heather, N., Hassan, E. 2013. Repellency and oviposition deterrence effects of plant essential and vegetable oils against female Queensland fruit fly Bactrocera tryoni (Froggatt) (Diptera: Tephritidae). Australian Journal of Entomology 52: 379-386.

Hochuli, D.F. 2001. Insect herbivory and ontogeny: How do growth and development influence feeding behavior, morphology and host use. Austral Ecology 26: 563-570.

Isman, M.B. 2006. Botanical insecticides, deterrents, and repellents in modern agriculture and an increasingly regulated world.Annual Review of Entomology 51: 45-66.

Khattak, M.K., Rashid, M.M., Abdullah, K. 2009. Effect of neem derivatives on infestation, settling and oviposition of melon fruit fly (Bactrocera cucurbitae Coq.) (Tephritidae: Diptera). Pakistan Entomologist 31: 11-16.

Lemoyne, P., Vicent, C., Gaul, S., Mackenzie, K. 2008. Kaolin affects blueberry maggot on fruit. Journal of Economic Entomology 101: 118-125.

Leskey, T.C., Wright, S.E., Glenn, M.,Puterka, G.J. 
2010. Effect of surround WP on behavior and mortality of apple maggot (Diptera: Tephritidae). Journal of Economic Entomology 103: 394-401.

Maia, M.F., Moore, S.J. 2011. Plant-based insect repellents: a review of their efficacy, development and testing. Malaria Journal 10: 1-15.

Miot, H.A., Batistella, R.F., Batista, K.A., Volpato, D.E.C., Augusto, L.S.T., Madeira, N.G., Haddad, V.,Miot, L.D.B. 2004. Comparative study of the topical effectiveness of the andiroba oil (Carapa guianensis) and DEET 50\% as repellent for Aedes sp. Revista do Instituto de Medicina Tropical de São Paulo 46: 253-256.

Minost, C. Disponível em: http://www.inra.fr/ hyppz/CULTURES/6c---004.htm. Acesso em: 17 de Jan. 2014.

Nunes, M.Z., Santos, R.S.S., Boff, M.I.C., Rosa, J.M. 2013. Bioatividade de extratos vegetais e inseticidas microbianos sobre lagartas de Chabuata major (Gueneé, 1852) (Lepidoptera: Noctuidae). Entomotropica 28: 11-16.

Rosa, J.M., Boff, M.I.C., Gonçalves, P.A., Boff, P., Nunes, M.Z. 2013. Andiroba oil (Carapa guianensis Aubl) in the capture of the fruit fly ( Anastrepha fraterculus Wiedemann) in Feijoa (Acca sellowiana (Berg) Burret). Idesia 31: 97-101.

Scoz, P.L., Botton, M., Garcia, M.S. 2004. Controle químico de Anastrepha fraterculus (Wied.) (Diptera: Tephritidae) em laboratório. Ciência Rural 34:1689-1694.

Silva, M.A., Bezerra-Silva, G.C.D., Vendramim, J.D., Mastrangelo, T. 2013. Sublethal effect of neem extract on mediterranean fruit fly adults. Revista Brasileira de Fruticultura 35:93-101.

Verde, G.L., Caleca, V., Verde, V.L. 2011. The use of kaolin to control Ceratitis capitata in organic citrus groves. Bulletin of Insectology 64: 127-134.

Zenzon M.,Trazilbo J.P.J.,Panelli A. 2005. Controle Alternativo de Pragas e Doenças, EPAMIG, Viçosa, Brasil, 362p. 